\title{
PARÂMETROS RACIONAIS DE AFERIÇÃO DO REAL CONTEÚdO DAS HIPÓTESES QUE ENSEJAM O JULGAMENTO MONOCRÁTICO DO ART. 557 DO CÓDIGO DE PROCESSO CIVIL BRASILEIRO À LUZ DO PRINCÍPIO DA COLEGIALIDADE
}

\author{
RATIONAL PARAMETERS OF MEASUREMENT OF THE REAL CONTENT OF THE \\ HIPOTHESYS THAT GIVES RISE TO THE MONOCRATIC JUDGMENT OF THE \\ BRAZILIAN CODE OF CIVIL PROCEDURE ARTICLE 557 IN THE LIGHT OF THE \\ PRINCIPLE OF COLLEGIALITY
}

\section{Ludmilla Camacho Duarte Vidal*}

Sumário: Introdução. 1. O princípio da colegialidade. 2. O princípio da colegialidade e as decisões judiciais. 3. Hipóteses de incidência do art. 557 do CPC. 3.1. Manifesto descabimento. 3.1.1. Recurso manifestamente inadmissível. 3.1.2. Recurso manifestamente prejudicado. 3.2. Manifesta improcedência. 3.2.1 Recurso manifestamente improcedente. 3.2.2. Recurso em confronto com súmula ou jurisprudência dominante. 4. Tendências e expectativas do novo código - a força da jurisprudência. Conclusão. Referências.

Resumo: O presente estudo propõe uma imersão nos fundamentos inerentes ao princípio da colegialidade, destacando sua natureza jurídica de norma constitucional implícita em caso de inconformismo e, portanto, passível de ponderação com outras garantias constitucionais, com o fito de demonstrar que as hipóteses que ensejam o julgamento monocrático, notadamente aquelas previstas no artigo 557, caput, do CPC, padecem de melhor hermenêutica. Procede-se à superação dos conceitos jurídicos indeterminados veiculados pelo dispositivo, com ênfase na terminologia jurisprudência dominante, face à dificuldade contemporânea de estabelecer o seu real conteúdo, bem assim o modo de aferi-la no caso concreto; atentando-se, ainda, para a nova metodologia trazida pelo Código de Processo Civil projetado.

\footnotetext{
* Universidade Federal de Juiz de Fora.
} 


\section{Volume VIII | Número 2 | Ano 2013}

Palavras-Chave: ampliação dos poderes do relator; art. 557 do CPC; princípio da colegialidade; manifesta improcedência; jurisprudência dominante.

Abstract: The present article proposes a deepening of the fundamentals inherent to the principle of collegiality, highlighting its juridical nature of an implied constitucional norm in cases of nonconformity and, therefore, subject to balancing with other constitucional guarantees in order to show that the hypothesis which allows the monocratic trial by the judge rapporteur, notedly those established in Article 557 of the Civil Process Code, need better hermeneutics. It proceeds to overcome the indeterminate legal concepts contained in the norm, with emphasis on the prevailing jurisprudence terminology, due to the contemporary difficulty of establishing its real content, as well as the way to measure it in an individual case; it pays attention, furthermore, to the new methodology brought by the Code of Civil Procedure drafted.

Keywords: expansion of the powers of the judge rapporteur; article 557 of the Civil Process Code; principle of collegiality; manifestly unfounded; prevailing jurisprudence.

\section{INTRODUÇÃO}

É cediço que o sistema recursal brasileiro se descortina num dos principais agentes causadores da morosidade do aparato de prestação jurisdicional, frente à impossibilidade, na atual conjuntura, de a máquina judiciária atender às múltiplas pretensões que lhe são requeridas a todo tempo, aliado ao momento de transição em que a civil law começa a se valer de mecanismos processuais solidificados pela common law, como o notório e crescente prestígio aos precedentes judiciais. A conjugação destes fatores desencadeou inúmeras reformas iniciadas desde a década de 90, voltadas para a garantia fundamental da construção de um instrumento processual acessível à todos, com respostas tempestivas e resultados justos.

Nesse rumo, flagrante foi o advento de alterações legislativas no sentido de otimizar o julgamento dos recursos perante os tribunais, como, verbi gratia, a criação da súmula vinculante, a repercussão geral em sede de recurso extraordinário, o julgamento dos recursos 


\section{Volume VIII | Número 2 | Ano 2013}

por amostragem e, notadamente, a considerável ampliação dos poderes do relator para exercer, em hipóteses previstas na legislação, o juízo de mérito nos recursos, desde que reservada a possibilidade de impugnação desta decisão por meio da interposição do agravo interno ao órgão colegiado, o qual seria competente para o julgamento do recurso inaugural.

No mesmo panorama, as Leis n. 9.139/1995 e 9.756/1998 foram responsáveis pelo ajuste do art. 557 do CPC aos moldes da tendência anteriormente demonstrada, a qual já vinha sendo prevista em diplomas normativos esparsos, como na Lei Orgânica da Magistratura Nacional; no Regimento Interno do Supremo Tribunal Federal (RISTF) - art. 21, §2 $2^{\circ}$ com redação atribuída pela Emenda Regimental 2/85-, bem como no Regimento Interno do Superior Tribunal de Justiça (RISTJ) - art. 34, XVIII. ${ }^{1}$

Com o advento da reforma traçada pela Lei n. 9.756/1998, manteve-se a redação do caput do art. 557 do CPC, sendo inserido o $\$ 1^{\circ}$-A ao art. 557 do CPC; e como uma dentre outras providências de atribuir legitimidade à decisão singular, fez por bem o legislador ao disponibilizar a possibilidade de interposição do agravo interno à parte detentora de interesse recursal, nos termos do art. 557, $\S 1^{\circ}$ do $\mathrm{CPC}$, fazendo com que a última palavra pertença ao juiz natural do recurso, que é sempre o órgão colegiado.

A pesquisa em questão se mostra necessária neste momento processual em que, passados mais de quatorze anos da edição da Lei n. 9.756/1998, as hipóteses que ensejam o julgamento monocrático do art. 557 do CPC ainda requerem a fixação de parâmetros racionais de compreensão e balizamento, que será efetivada após a superação dos conceitos jurídicos indeterminados veiculados pela norma, sobretudo, jurisprudência dominante e manifestamente improcedente; bem como pela demonstração da postura mais adequada do magistrado singular na oportunidade em que não provê o recurso manifestamente improcedente e não conhece da pretensão recursal destoante de entendimento sumulado ou da tese jurídica dominante do tribunal local, Supremo Tribunal Federal (STF) ou Tribunal Superior (STJ).

Outrossim, no presente momento de finalização do trâmite do Novel Código perante o Plenário do Congresso Nacional, a questão posta ainda se torna mais séria frente aos anseios da sociedade por uma nova codificação, hábil a propiciar, nas palavras de Luiz Fux², "um

\footnotetext{
${ }^{1}$ CIANCI, Mirna. A Lei 9.756/1988 (arts. 544, $3^{\circ}$ e 557, $\S 1^{\circ}$ A e $3^{\circ}$ do CPC) e a ampliação dos poderes do relator - dez anos depois. Revista dos Tribunais, São Paulo, n. 157, Março/2008, p. 165.

${ }^{2}$ FUX, Ministro Luiz. Carta de encaminhamento do Anteprojeto do Novo Código de Processo Civil ao Senado Federal. Anteprojeto do Código de Processo Civil. Brasil. Congresso Nacional. Senado Federal: Presidência da
} 


\section{Volume VIII | Número 2 | Ano 2013}

processo mais ágil, capaz de dotar o país de um instrumento que possa enfrentar de forma célere, sensível e efetiva, as misérias e as aberrações que passam pela Ponte da Justiça”. Será que mais uma vez, sob o argumento de atribuir celeridade aos feitos, o princípio da colegialidade será comprometido? Qual a melhor técnica a ser empreendida para que, além da limitação do âmbito de incidência do caput do art. 557 do atual CPC, possa se contribuir para a eficácia da norma ${ }^{3}$ prevista pela nova legislação que se desponta?

\section{O PRINCÍPIO DA COLEGIALIDADE}

Inicialmente, cumpre investigar a natureza jurídica do princípio da colegialidade, e, por conseguinte, de onde são emanados seus fundamentos racionais axiológicos, tal como os dispositivos que lhe dão suporte. Será o princípio da colegialidade uma garantia fundamental? Poderá sofrer ponderação com outros princípios constitucionais? Até que ponto poderá ser restringido? Buscando responder as duas primeiras indagações levantadas, sendo certo que a última será enfrentada mais adiante, recorre-se inicialmente ao princípio da separação dos Poderes, uma das garantias mais importantes à estrutura da atual organização política, destacando-se os ensinamentos de Gilmar Ferreira Mendes ${ }^{4}$, no sentido de reconhecer que tal norma-princípio consiste no alicerce básico inerente ao Estado de Direito:

O princípio da separação dos poderes adquiriu o status de uma forma que virou substância no curso do processo de construção e de aprimoramento do Estado de Direito, a ponto de servir de pedra de toque para se dizer da legitimidade dos regimes políticos, como se infere do célebre artigo XVI da Declaração dos Direitos do Homem e do Cidadão, de 1789, onde se declara que não tem constituição aquela sociedade em que não estejam assegurados os direitos dos indivíduos, nem

\footnotetext{
República. Brasília, 2010. Disponível em: 〈http://www.senado.gov.br/senado/novocpc/pdf/anteprojeto.pdf〉. Acesso em 08 de maio de 2013.

${ }^{3}$ Registra-se que o PLS no. 166/2010 trata da implementação do novo código, tendo como relator geral o Senador Valter Pereira. O projeto revisado na Câmara dos Deputados, correspondente ao PL nº 8.046/2010, de relatoria do Deputado Paulo Teixeira, obteve aprovação do seu texto-base pelo plenário da Câmara em 05 de Novembro de 2013, adquirindo a presente redação: “Art. 945. Incumbe ao relator: (...) III - não conhecer de recurso inadmissível, prejudicado ou que não tenha impugnado especificamente os fundamentos da decisão recorrida; IV - negar provimento a recurso que for contrário a: a) súmula do Supremo Tribunal Federal, do Superior Tribunal de Justiça ou do próprio tribunal; b) acórdão proferido pelo Supremo Tribunal Federal ou pelo Superior Tribunal de Justiça em julgamento de recursos repetitivos; c) entendimento firmado em incidente de resolução de demandas repetitivas ou de assunção de competência. V - depois de facultada, quando for o caso, a apresentação de contrarrazões, dar provimento ao recurso se a decisão recorrida for contrária a: a) súmula do Supremo Tribunal Federal, do Superior Tribunal de Justiça ou do próprio tribunal; b) acórdão proferido pelo Supremo Tribunal Federal ou pelo Superior Tribunal de Justiça em julgamento de recursos repetitivos; c) entendimento firmado em incidente de resolução de demandas repetitivas ou de assunção de competência (...)Parágrafo único. Antes de considerar inadmissível o recurso, o relator concederá o prazo de cinco dias ao recorrente para que seja sanado vício ou complementada a documentação exigível”.

Disponível em: <http://s.conjur.com.br/dl/minuta-cpc-votada-camara.pdf>, acessado em 30 de novembro de 2013.

${ }^{4}$ BRANCO, Paulo Gustavo Gonet; COELHO, Inocêncio Mártires; MENDES, Gilmar Ferreira. Curso de Direito Constitucional. 4. ed. São Paulo: Saraiva, 2009, pp. 177-178.
} 


\title{
Volume VIII | Número 2 | Ano 2013
}

separados os poderes estatais. Na Constituição do Brasil, esse princípio que está estampado no seu art.2 $^{\circ}$, onde se declara que são Poderes da União independentes e harmônicos - o Legislativo, o Executivo e o Judiciário, é de tamanha importância que possui o status de cláusula pétrea, imune, portanto, a emendas, reformas ou revisões que tentem aboli-lo da Lei Fundamental. (negritado)

O princípio da separação do Poderes, consagrado pelas ideias preconizadas por Montesquieu no Século das Luzes, notadamente, em sua obra “O Espírito das Leis”, possui duas dimensões complementares ${ }^{5}$ apontadas por J.J Gomes Canotilho ${ }^{6}$ : (1) a separação como 'divisão', 'controle' e 'limite' do poder - dimensão negativa; (2) a separação como ‘constitucionalização', 'ordenação' e 'organização' do poder do Estado tendente a decisões funcionalmente eficazes e materialmente justas (dimensão positiva). A sutileza retórica reside no arremate entre a separação e independência dos Poderes e a colegialidade, justamente por esta consagrar aquela ${ }^{7}$, questão trazida por Diogo Ferraz Lemos Tavares $^{8}$ e merecedora de realce:

\begin{abstract}
A Colegialidade indica a necessidade de que, tanto quanto possível, os julgamentos sejam tomados por mais de uma pessoa, obviamente em número ímpar para se evitar dissensos ou atribuições arbitrárias de maior peso a um dos julgadores. Tal necessidade é justificada por motivos tão singelos quanto poderosos, que encerram o seguinte círculo virtuoso: (a) um órgão colegiado está menos sujeito a pressões externas (provenientes de outro órgão de poder, por exemplo) do que uma única pessoa; (b) essa blindagem frente às pressões torna o órgão judicante mais independente e autônomo, pois as suas decisões, ainda que contrárias a interesses poderosos - mas não agasalhados pelo ordenamento jurídico -, não lhe ensejarão represálias; (c) tais independência e autonomia tornam possível que o órgão colegiado paute suas decisões apenas e tão somente no ordenamento jurídico, ou seja, naquilo que aquele órgão considere como a solução verdadeiramente justa para o caso, e não em determinações impostas por terceiros ou mesmo por uma das partes; (d) todos esses fatores, aliados ao fato de que é mais provável que a melhor solução surja no debate plural do que na imposição unipessoal, incutem nos cidadãos-partes a confiança no sistema e a ideia de que a solução emanada do órgão colegiado, ainda que lhe seja contrária, surgiu exclusivamente da análise do caso concreto à luz do ordenamento jurídico, e não em razão da vontade de um dos envolvidos, o que contribui para o reconhecimento e aceitação social daquelas decisões, imprescindíveis para o funcionamento da sociedade. (negritado)
\end{abstract}

${ }^{5}$ CARVALHO FILHO, José dos Santos. Manual de Direto Administrativo. 23. ed. Rio de Janeiro: Lumen Juris, 2010, p. 3.

${ }^{6}$ CANOTILHO, J.J. Gomes. Direito Constitucional e Teoria da Constituição. Coimbra: Almedina, 2007, pp. 251-252.

7 COHENDET, Marie-Anne. La Collégialité des Juridictions: un principe en voie de disparition. Revue Française de Droit Constitutionnel, Paris, n. 68, 2006, pp. 713-735, apud MENDONÇA, Henrique Guelber de. O Princípio da colegialidade e o papel do relator no processo civil brasileiro. Revista Eletrônica de Direito Processual, Rio de Janeiro, 1. ed., Outubro/2007. Disponível em: <http://www.redp.com.br/arquivos/redp_1a_edicao_rj.pdf>, acessado em 10 de junho de 2013.

${ }^{8}$ TAVARES, Diogo Ferraz Lemos. Princípio da Colegialidade: fundamento constitucional e necessidade de sua observância nos processos judiciais e administrativos - legitimidade/ilegitimidade de exceções. Revista Eletrônica de Direito Processual, Rio de Janeiro, a. 5, v. VIII, Julho/2011. Disponível em: < http://www.redp.com.br/arquivos/redp_8a_edicao.pdf>. Acesso em 08 de julho de 2013. 
Entrementes, registra-se que além do respaldo demonstrado acima, a colegialidade também decorre da garantia dada ao jurisdicionado em receber uma tutela justa e adequada aos princípios balizadores do devido processo legal. O direito ao processo justo ${ }^{9}$ - giusto processo $^{10}$, fair trial - é assegurado de forma expressa pela Carta Republicana, conforme se depreende da redação do art. $5^{\circ}$, incisos XXXV, LV, LXXVIII.

Portanto, preciosa é a compreensão de que os cuidados dedicados pelo legislador originário ao princípio da colegialidade provêm, certamente, da conjugação entre a máxima da Separação e Independência tripartite dos Poderes, aliada à garantia constitucional da tutela justa e efetiva, sendo este último o cerne de todo o Processo Civil cuja função consiste, em última análise, na concretização do acesso à ordem jurídica justa ${ }^{11}$. Observa-se que o direito ao processo justo e efetivo ${ }^{12}$ deverá comportar os juízos de proporcionalidade e razoabilidade $^{13}$ e, é justamente este viés inexoravelmente axiológico o responsável pelo enquadramento da colegialidade como norma-princípio, passível de proteção adequada pelo ordenamento.

Partindo da ideia de ser um princípio constitucional não expresso, porém verdadeiro sustentáculo da efetivação de Direitos Fundamentais, necessário se faz observar que é emanado dos art. 93, incisos X e XI; 94; 101; 104 e 107 da Constituição Federal ${ }^{14}$. Não

\footnotetext{
9 “O direito ao processo justo visa a assegurar a obtenção de uma decisão justa. Ele é o meio pelo qual se exerce pretensão à justiça (Justizanspruch) e pretensão à tutela jurídica (Rechtsschutzanspruch). Esse é o seu objetivo central dentro do Estado Constitucional" (MITIDIERO, Daniel. Direito Fundamental ao processo justo, p. 5. Disponível em: <http://www.rkladvocacia.com/arquivos/artigos/art_srt_arquivo20130419164953.pdf〉. Acesso em 28 de novembro de 2013).

No mesmo sentido: OLIVEIRA, Carlos Alberto Alvaro de. Os Direitos Fundamentais à Efetividade e à Segurança em Perspectiva Dinâmica, pp. 2-25.

Disponível em: < http://www.oab.org.br/editora/revista/users/revista/1222961767174218181901.pdf >. Acesso em 20 de novembro de 2013.

${ }^{10}$ A observação do direito ao processo justo consiste em condição necessária e indispensável para obtenção de decisões justas (TARUFFO, Michele. Idee per una Teoria della Decisione Giusta, Sui Confini - Scritti sulla Giustizia Civile. Bologna: Il Mulino, 2002, p. 224, apud MITIDIERO, Daniel. Op. cit., p.5).

${ }^{11}$ Não é suficiente que o ordenamento jurídico garanta a igualdade formal dos homens perante a lei quando as partes não puderem participar, em igualdade de condições, do complexo aparato de tutela de direitos que é o processo (CAPPELLETTI, Mauro; GARTH, Bryant. Acesso à Justiça. Tradução de Ellen Gracie Northfleet. Porto Alegre: Fabris 1988, Reimpresso em 2002).

12“"Processo efetivo é aquele que, observado o equilíbrio entre os valores segurança e celeridade, proporciona às partes o resultado desejado pelo direito material. Pretende-se aprimorar o instrumento estatal destinado a fornecer a tutela jurisdicional. Mas constitui perigosa ilusão pensar que simplesmente conferir-lhe celeridade é suficiente para alcançar a tão almejada efetividade. Não se nega a necessidade de se reduzir a demora, mas não se pode fazê-lo em detrimento do mínimo de segurança, valor também essencial ao processo justo". (BEDAQUE, José Roberto dos Santos. Efetividade do Processo e Técnica Processual. 3. ed. São Paulo: Malheiros, 2010, p. 49).

${ }^{13}$ ÁVILA, Humberto. O que é "devido processo legal”. In: DIDIER JR., Fredie (Org.). Leituras complementares de Processo Civil. 5. ed. Salvador: Jus Podivm, 2010, p. 354.

14 “Art. 93 (...) X: as decisões administrativas dos tribunais serão motivadas e em sessão pública, sendo as disciplinares tomadas pelo voto da maioria absoluta de seus membros. XI: nos tribunais com número superior a vinte e cinco julgadores, poderá ser constituído órgão especial, com o mínimo de onze e o máximo de vinte e
} 


\title{
Volume VIII | Número 2 | Ano 2013
}

demanda esforço constatar que a colegialidade é expressamente assegurada pelo CPC, notadamente pelo art. 476 e seguintes. Pois bem, o próprio art. 557, caput, do CPC, tema desta dissertativa, reconhece a força normativa da colegialidade, à medida em que firma critérios que autorizam o julgamento monocrático em sede recursal. Leonardo Greco ${ }^{15}$ vislumbra seu viés estrutural e assevera:

\begin{abstract}
Vejo na colegialidade não só uma garantia individual do jurisdicionado, mas uma garantia estrutural, especialmente nos sistemas, com o nosso, de juiz monocrático de $1^{\circ}$ grau. Que probabilidade de acerto e de justiça tem uma decisão de um só juiz, revista também por um só juiz? $O$ aumento da probabilidade de acerto e de justiça das decisões que constitui um dos fundamentos do princípio do duplo grau de jurisdição fica grandemente comprometido pela monocratização dos julgamentos das instâncias superiores, fenômeno recentemente agravado entre nós com a vulgarização dos julgamentos por despacho unipessoais do relator, com fundamento nas alterações que a lei $\mathrm{n}^{\circ} \mathbf{9 . 7 5 6 / 9 8}$ introduziu no art. 557 do CPC. A colegialidade é também um importante fator de busca da legitimidade do judiciário, ou seja, de persuasão do jurisdicionado de que a sua causa foi julgada por uma junta de juízes, que discutiram a matéria procurando em conjunto encontrar a solução mais justa: juízes que revelaram o direito das partes no exercício mais autêntico do mandato recebido do povo e sob o mais eficaz mecanismo de controle, aquele que cada julgador exerce sobre o comportamento dos demais, porque a decisão que todos buscam vai influir na reputação de cada um. (negritado)
\end{abstract}

Desta feita, o multicitado princípio da colegialidade deve ser compreendido como verdadeira garantia constitucional implícita, pois além de consagrar, efetivar e confirmar dois princípios inerentes ao Estado Democrático de Direito, conta com previsão expressa na legislação processual civil e, pelo fato de possuir elevada carga valorativa, passível será de adequação - juízo de ponderação - aos fins preconizados pelo Estado em determinado momento histórico. Resta saber até que ponto.

\section{O PRINCÍPIO DA COLEGIALIDADE E AS DECISÕES JUDICIAIS}

Conforme se extrai das normas de competência recursal e de composição dos tribunais pátrios asseguradas pela Magna Carta Federal de 1988 (v.g, artigos 93, 94, 101, 104 e 107),

cinco membros, para o exercício das atribuições administrativas e jurisdicionais delegadas da competência do tribunal pleno, provendo-se metade das vagas por antiguidade e a outra metade por eleição pelo tribunal pleno (...) Art. 94. Um quinto dos lugares dos Tribunais Regionais Federais, dos Tribunais dos Estados, e do Distrito Federal e Territórios será composto de membros, do Ministério Público, com mais de dez anos de carreira, e de advogados de notório saber jurídico e de reputação ilibada, com mais de dez anos de efetiva atividade profissional, indicados em lista sêxtupla pelos órgãos de representação das respectivas classes. (...) Art. 101. O Supremo Tribunal Federal compõe-se de onze Ministros, escolhidos dentre cidadãos com mais de trinta e cinco e menos de sessenta e cinco anos de idade, de notável saber jurídico e reputação ilibada (...) Art. 104. O Superior Tribunal de Justiça compõe-se de, no mínimo, trinta e três Ministros. (...) Art. 107. Os Tribunais Regionais Federais compõem-se de, no mínimo, sete juízes, recrutados, quando possível, na respectiva região e nomeados pelo Presidente da República dentre brasileiros com mais de trinta e menos de sessenta e cinco anos". (...)

${ }^{15}$ GRECO, Leonardo. A Falência dos sistemas de recursos. Revista dialética de direito processual, São Paulo, v. 1, Abril/2003, p. 103. 


\section{Volume VIII | Número 2 | Ano 2013}

bem assim da sistemática delineada no CPC e dos regimentos internos dos tribunais ${ }^{16}$, os recursos deverão, em tese, ser analisados pelo órgão colegiado em sessão pública na sede do tribunal ad quem. Estes, por sua vez, estruturam-se justamente para a emissão de decisões plurais e, em face da impossibilidade de todos os membros apreciarem pessoalmente as demandas submetidas ao crivo da Corte, figura-se medida dotada de mais elevado grau de eficiência a sua divisão em órgãos fracionários, sendo cada caso atribuído primeiramente a um de seus componentes: o relator.

Feita a distribuição, são os autos encaminhados ao relator competente, o qual possui a função de averiguar a contenda e fixar os pontos controvertidos por meio de um relatório que irá fazer parte do acórdão ${ }^{17}$. Elaborado o memorial pertinente, caberá ao relator o encaminhamento dos autos ao Presidente do órgão colegiado, que designará o dia certo para o julgamento em tribuna, no que mandará publicar a pauta no Órgão Oficial, sendo esta também afixada na entrada da sala em que for realizada a votação.

Contudo, tal procedimento tradicional e suas garantias fundamentais processuais vêm se revelando alvo de mitigação pelo legislador pátrio face à intensa multiplicação do apelo às instâncias de revisão das decisões proferidas no primeiro grau, aliada à crescente valorização dos precedentes firmados pelos Tribunais Superiores; fatores que desencadearam a proliferação de diplomas normativos que trazem em seu bojo a outorga de poderes ao relator para apreciar previamente os pressupostos de admissibilidade, sendo adiante acentuada tal orientação com autorização de adentrar no mérito monocraticamente. Nesse rumo, despontaram as Leis n. 9.139/1995 e 9.756/1998 com, dentre outras incumbências, a de atribuir nova redação ao art. 557 do $\mathrm{CPC}$, passando a assentir não só a apreciação das questões que precedem ao mérito, mas também o exame da própria tese jurídica defendida, desde que, obviamente, atentadas certas condições, que por ora se dizem flagrantemente fluidas e carentes de delimitação objetiva.

\footnotetext{
${ }^{16}$ Ad exemplum, o regimento interno do Tribunal de Justiça de Minas Gerais - TJMG, especificamente no art. 37, faz a seguinte previsão: "art. 37: Compete às câmaras cíveis processar e julgar: (...) II - em turma de três julgadores: a) o mandado de segurança contra o ato ou decisão do juiz de direito, desde que relacionados com processos cujo julgamento, em grau de recurso, seja de sua competência, excetuada a hipótese prevista na alínea $b$ do inciso II do art. 39 deste regimento; b) em feito de sua competência, restauração de autos perdidos, habilitação incidente, suspeição oposta a desembargador, a procurador de justiça e a juiz de direito, além de outros incidentes que ocorrerem; c) recurso de decisão de primeira instância (...)" (negritado) Nesse mesmo sentido é a redação do art. 19 do regimento interno do Tribunal de Justiça do Rio Grande do Sul - TJRS: "Compete, ainda, às Câmaras Separadas: (...) II julgar: os recursos das decisões dos Juízes de primeiro grau (...)".

${ }^{17}$ Art. 121 do regimento interno do TJMG: "O acórdão será lavrado pelo relator e conterá: I - a ementa, que terá início com a palavra ou expressão designativa do tema principal, objeto do julgamento, bem como a súmula do que ficou decidido" (...) Na mesma linha prevê o art. 202 do regimento interno do TJRS: "Art. 202. O acórdão será redigido pelo Relator e apresentado para publicação no prazo de trinta (30) dias (...)".
} 


\section{Volume VIII | Número 2 | Ano 2013}

Muito se questionou ${ }^{18}$ acerca dessa tomada de decisão adotada pelo legislador ordinário, sobretudo por representar uma progressiva relativização da colegialidade e do princípio do juiz natural em sede recursal. Isso porque, o princípio da colegialidade, analisado sob a perspectiva jurisdicional, apresenta íntima relação com o princípio do juiz natural ${ }^{19}$ pois o juiz natural dos recursos é o órgão colegiado - e, sendo assim, poderiam restar ambos violados no caso de haver decisão monocrática pelo relator, se este passa a representar a vontade do órgão colegiado.

Contudo, já restou demonstrado que o princípio da colegialidade poderá, em casos específicos, ser relativizado em nome de outros princípios constitucionais - porém jamais suprimido - o que, em última análise, implicaria também na flexibilização, nestas hipóteses, do princípio do juiz natural.

A relativização destas garantias fundamentais ocorre, sobretudo, nos casos previstos no artigo 557 do $\mathrm{CPC}$, desde que assegurada a possibilidade da decisão do relator ser questionada pela via do agravo interno, eis que, de acordo com Barbosa Moreira 20 "não seria possível subtrair de forma definitiva a apreciação do recurso ao órgão ad quem sem pôr em xeque a garantia do juiz natural".

É de se notar com total espanto que a doutrina ainda se revela tímida - conforme será demonstrado - na imposição de parâmetros de cognição restritiva à compreensão das hipóteses permissivas de julgamento monocrático do art. 557, caput, do CPC, deixando a

\footnotetext{
${ }^{18}$ Nesse rumo, por exemplo: MOREIRA, José Carlos Barbosa. Comentários ao Código de Processo Civil. v. V. 11. ed. Rio de Janeiro: Forense, 2003, pp. 680-682; CARNEIRO, Athos Gusmão. Poderes do relator e Agravo Interno - Art. 557, 544 e 545 do CPC. Doutrinas essenciais de Processo Civil. v. 7. São Paulo: Revista dos Tribunais, 2011; DINAMARCO, Cândido Rangel. O relator, a jurisprudência e os recursos. In: WAMBIER, Teresa Arruda Alvim; NERY JÚNIOR, Nelson (Orgs.). Aspectos polêmicos e atuais dos recursos cíveis de acordo com a Lei 9.756/98. São Paulo: Revista dos Tribunais, 1998, p.132; FRANÇOLIN, Wanessa de Cássia. A ampliação dos poderes do relator nos recursos cíveis. Rio de Janeiro: Forense, 2006.

No mesmo sentido, também se encontra o voto do Ministro Celso de Mello no julgamento que deu origem ao informativo 285 do STF, verbis: "[...] Cumpre acentuar, neste ponto, que o Pleno do Supremo Tribunal Federal reconheceu a inteira validade constitucional da norma legal que inclui, na esfera de atribuições do Relator, a competência para negar trânsito, em decisão monocrática, a recursos, pedidos ou ações, quando incabíveis, estranhos à competência desta Corte, intempestivos, sem objeto ou que veiculem pretensão incompatível com a jurisprudência predominante do Tribunal (RTJ 139/53 - RTJ 168/174-175). Nem se alegue que esse preceito legal implicaria transgressão ao princípio da colegialidade, eis que o postulado em questão sempre restará preservado ante a possibilidade de submissão da decisão singular ao controle recursal dos órgãos colegiados no âmbito do Supremo Tribunal Federal, consoante esta Corte tem reiteradamente proclamado (RTJ 181/11331134, Rel. Min. CARLOS VELLOSO - AI 159.892-AgR/SP, Rel. Min. CELSO DE MELLO)”.

${ }^{19} \mathrm{O}$ princípio do juiz natural garante que ninguém poderá ser privado do julgamento por juiz independente e imparcial, indicado pelas normas constitucionais e legais. Isso porque Constituição proíbe os chamados tribunais de exceção, instituídos para o julgamento de determinadas pessoas ou de crimes de determinada natureza, sem previsão constitucional - art. $5^{\circ}$, inc. XXXVII (CINTRA, Antônio Carlos Araújo; DINAMARCO Cândido Rangel; GRINOVER Ada Pellegrini. Teoria Geral do Processo. 26. ed. São Paulo: Malheiros, 2010, p. 158).

${ }^{20}$ MOREIRA, José Carlos Barbosa. Comentários ao Código de Processo Civil. v. V. 11. ed. Rio de Janeiro: Forense, 2003, p. 683.
} 


\section{Volume VIII | Número 2 | Ano 2013}

cargo dos magistrados a difícil tarefa de estabelecer o real conteúdo dos pressupostos de aplicação.

Nesta medida, abre-se espaço para a exposição do princípio da colegialidade inserido nas decisões judiciais no almejar de adiante se traçar os contornos hermenêuticos necessários à assimilação do real conteúdo das disposições constadas no art. 557 do CPC, caput, com o fito de garantir a máxima atuação, a mínima restrição e a inconcebível supressão desta garantia constitucional.

É sabido que a atuação do juiz solitário, baseada na representação da vontade estatal, obtém legitimação na oportunidade em que o magistrado expõe, pormenorizadamente, as razões de decidir utilizadas no enfretamento do caso apreciado, conforme preceitua o art. 93, IX da Constituição Federal de 1988. De fato, é justamente a fundamentação esposada pelo órgão julgador que o reconhece ser "porta voz" do Estado, isto porque conforme se tem conhecimento, os integrantes do Poder Judiciário não são eleitos pelo povo, mas habilitados por meio da aprovação em Concurso Público de provas e títulos, nos termos do art. 93, I da Magna Carta.

Com efeito, em que pese o juízo do primeiro grau ser efetivado pelo desempenho do magistrado singular, impera na seara recursal a regra tradicional de observância ao princípio da colegialidade, na medida em que os julgamentos em tribuna são essencialmente caracterizados pela atuação de no mínimo três julgadores que compõe as turmas ou câmaras, dependendo do tribunal. Outra característica peculiar de estruturação dos tribunais brasileiros se refere à sua formatação ideal, em virtude da notável mescla dos critérios de promoção do magistrado a quo, sendo que ora é ascendido pelo merecimento, ora pela antiguidade, alternadamente.

Pela observância destes requisitos impostos pelo Constituinte, figura-se lógica a conclusão de que pretendeu o legislador conceder aos tribunais a possibilidade de extrair da técnica somada à maturidade a prolação de decisões finais mais ajustadas à realidade casuística do que aquela impugnada e, além disso, por se a decisão proferida em segunda instância fruto de um consenso tomado a partir de um discurso lógico e racional, apresentará maior possibilidade de êxito e adequação à realidade casuística, sendo que ainda, os critérios de merecimento e antiguidade exigidos para a composição do órgão colegiado alentam tanto o jurisdicionado quanto os aplicadores do Direito, por saberem que da técnica e da experiência, sairão, indubitavelmente, decisões mais acertadas. 


\section{Volume VIII | Número 2 | Ano 2013}

É forçoso ressaltar que o exame colegiado constitui o verdadeiro traço, essência, da atuação dos tribunais, haja vista que o debate travado entre aqueles que apreciam o caso concreto constitui fator imprescindível à reflexão e ao amadurecimento da causa; porém, desde que se dê coligado com a atuação de fato das partes litigantes, que devem participar efetivamente do feito (ao menos ter essa possibilidade) na defesa de suas teses jurídicas, tanto na peça recursal redigida, quanto oralmente, pela via da sustentação oral.

Insta esclarecer que a composição dos tribunais de segunda instância, que atuam de uma maneira geral como Cortes revisoras das matérias de fato e de direito, segue os moldes dos artigos 94 e 115 da Suprema Carta, onde se tem expressamente estabelecido que os Tribunais de Justiça dos Estados, do Distrito Federal e os Tribunais Regionais Federais serão compostos por magistrados oriundos do primeiro grau, pelo reconhecimento dos critérios já mencionados: merecimento e antiguidade. ${ }^{21}$

Merece destaque, ainda, que consiste em determinação constitucional que precisamente 1/5 das vagas ocupadas pelos desembargadores serão destinadas aos advogados indicados pela $\mathrm{OAB}$ bem como aos membros do Ministério Público, o que denota o objetivo de estimular a dialética necessária ao consenso final do colegiado, considerando que cada um de seus componentes traz consigo realidades e contextos de atuação diversos, porém, essenciais à construção do mais justo desfecho ao caso apreciado. Nesse rumo, já se restou induvidosa a constatação de que a colegialidade - verdadeiro princípio constitucional implícito - é requisito crucial da atuação dos tribunais, justamente pela segurança de que as teses jurídicas defendidas serão alvo de apreciação "qualitativa e quantitativa"; alinhando-se nesse viés, Henrique Guelber de Mendonça ${ }^{22}$ :

O que o julgamento por órgão colegiado pode propor aos recorrentes é um aumento da probabilidade de acerto. É o mesmo que alargar e solidificar a base sobre a qual se edifica uma construção qualquer. $O$ recurso é o remédio utilizado pelo vencido na ânsia de se ver livre de uma sentença desafinada com sua própria justiça. Não há garantia de que seu ponto de vista prevalecerá ou não. $O$ fato de alguém recorrer não pode conduzir ao raciocínio de que o recorrente tem mais razão do que o recorrido ou vice-versa. A decisão tomada de forma conjunta é imprescindível em um país de primeira instância monocrática. Não há razão para que os tribunais se componham de juízes monocráticos revisores, o que afrontaria nossa própria Constituição, fugindo de seu espírito. (negritado)

\footnotetext{
${ }^{21}$ MENDONÇA, Henrique Guelber de. O Princípio da colegialidade e o papel do relator no processo civil brasileiro. Revista Eletrônica de Direito Processual, Rio de Janeiro, 1. ed., Outubro a Dezembro de 2007, p. 208. Disponível em: <http://www.redp.com.br/arquivos/redp_1a_edicao_rj.pdf〉, acessado em 10 de junho de 2013.

${ }^{22}$ Idem, Ibidem.
} 
Colaciona-se, ainda, o posicionamento adotado por Leonardo Greco ${ }^{23}$ :

\begin{abstract}
A colegialidade protege a independência dos julgadores que, por ela, se tornam menos suscetíveis de sucumbirem a pressões. Ademais, é garantia de maior igualdade nos julgamentos, que não representam a opinião de uma só pessoa; estimula decisões mais refletidas e moderadas, porque resultantes da troca de opiniões e de pontos de vista entre os julgadores; goza de maior legitimidade política, porque é pluralista na aplicação da lei, como o é o Parlamento, na sua elaboração. (negritado)
\end{abstract}

Logo, não se mostra adequado, muito menos razoável, que o nosso sistema de prestação jurisdicional, em que o primeiro grau é representado pela técnica de apenas um juiz solitário, seja conivente com um arranjo recursal que permita a reapreciação da matéria de direito unicamente por um julgador; é necessário que a doutrina e jurisprudência reconheçam a importância de se lutar contra a "monocratização" das decisões tomadas em tribuna, pois o princípio da colegialidade jamais poderá ser olvidado por aqueles que detêm a incumbência da produção legiferante, tal como pelos que fazem justiça.

\title{
3. HIPÓTESES DE APLICAÇÃO DO ART. 557 DO CPC
}

Conforme se extrai dos ensinamentos de Luiz Guilherme Marinoni e Sérgio Cruz Arenhart ${ }^{24}$, o texto legal (caput) abarca basicamente duas modalidades de outorga de poderes ao relator para agir solitariamente: a) manifesto descabimento; e b) manifesta improcedência. Tal divisão proposta é justificada pelo inadequado enquadramento estabelecido pelo texto normativo acerca das situações que o recurso se mostre manifestamente improcedente, bem assim que apresente tese jurídica confrontante com súmula ou jurisprudência dominante do tribunal local e dos Tribunais Superiores, como hipóteses pertinentes ao juízo de admissibilidade, em razão de constar o vocábulo "negar seguimento". Ademais, no que tange ao recurso manifestamente prejudicado, por padecer de interesse recursal, adapta-se perfeitamente às situações de manifesta inadmissibilidade.

\footnotetext{
${ }^{23}$ GRECO, Leonardo. Princípios de uma teoria geral dos recursos. Revista Eletrônica de Direito Processual, Rio de Janeiro, ano 4, v. V, 2010, p. 36. Disponível em: 〈http://www.redp.com.br/edicao_05.htm〉. Acesso em 17 de julho de 2013.

${ }^{24}$ ARENHART, Sergio Cruz; MARINONI, Luiz Guilherme. Curso de Processo Civil. v. 2. São Paulo: Revista dos Tribunais, 2013, p.585.
} 
3.1. Manifesto descabimento

\subsubsection{Recurso manifestamente inadmissível}

Indagar-se acerca da admissibilidade do recurso, significa perquirir se este possui os requisitos indispensáveis ao devido prosseguimento à análise meritória. Este exame, atinente à verificação dos pressupostos genéricos impostos pela lei para os recursos em geral e dos pressupostos específicos referentes a cada espécie recursal, realiza-se tanto pelo juízo "a quo" quanto "ad quem", devendo os órgãos jurisdicionais velar por sua verificação precisa, na medida em que envolve matéria de ordem pública.

Na presente pesquisa, adota-se a divisão proposta por Barbosa Moreira, que procede à separação dos pressupostos de admissibilidade recursal em dois grupos distintos: a) intrínsecos, que dizem respeito à decisão recorrida em si mesma considerada: cabimento, legitimidade em recorrer e o interesse recursal; e b) extrínsecos, referentes aos fatos supervenientes à decisão recorrida: regularidade formal, inexistência de fato impeditivo, modificativo ou extintivo do poder de recorrer e preparo. Em sede meritória, o órgão "ad quem" manifesta-se pelo improvimento ou provimento, seja para reformar (error in judicando) ou invalidar (error in procedendo) a decisão recorrida.

A primeira possibilidade de julgamento monocrático previsto pelo dispositivo em destaque refere-se ao recurso manifestamente inadmissível, logo, aquele que padece de um ou mais requisitos de admissibilidade, o que por certo não demanda maiores cuidados deste estudo, máxime à atuação essencialmente objetiva do relator.

\subsubsection{Recurso manifestamente prejudicado}

Inserida no conceito de recurso manifestamente inadmissível que será alvo de decisão monocrática, encontra-se a hipótese de o relator negar seguimento ao recurso quando este se restar manifestamente prejudicado - ou seja, em caso de perda do objeto da pretensão 
recursal $^{25}$-, desde que assentada num suporte fático incontroverso, resultando absolutamente evidente a desnecessidade do prosseguimento do feito. ${ }^{26}$

Chega-se à constatação de que as hipóteses de descabimento da peça recursal apresentadas não exprimem maiores complexidades, notadamente por seu viés objetivo, fato que não ocorre com o recurso manifestamente improcedente e aquele que apresenta manifesto confronto com súmula ou jurisprudência dominante, adiante examinado.

\subsection{Manifesta improcedência}

\subsubsection{Recurso manifestamente improcedente}

Ademais, mediante uma leitura perfunctória do caput, verifica-se que a norma prevê a possibilidade de o juiz monocrático negar seguimento ${ }^{27}$ ao recurso manifestamente improcedente, confrontante com súmula ou jurisprudência dominante do respectivo tribunal, STF ou de Tribunal Superior, sendo certo que manifesta improcedência não é o mesmo que confronto com súmula ou jurisprudência dominante, pois se assim o fosse, o legislador não firmaria previsão destas duas espécies de improcedência e, justamente é nesse ponto que reside grande parte de toda a gravidade da situação.

A compreensão acerca da manifesta improcedência submete-se à averiguação da natureza jurídica inerente à decisão monocrática. Pelo raciocínio que vem sendo traçado, tendo em vista as razões já expostas, o colegiado corresponde ao órgão dotado de competência para apreciar as demandas processadas nos tribunais e, por conseguinte, o poder do relator é apenas derivado e outorgado em hipóteses extremamente pontuais, o que significa dizer que, em tese, o juiz solitário deveria adotar a mesma postura que seria tomada por seu delegante. Nesse sentido arremata Nagib Slaibi Filho ${ }^{28}$ : “o provimento relatorial antecipa a

\footnotetext{
${ }^{25}$ Ver CAMBI, Acácio. Aspectos polêmicos na aplicação do art. 557 do CPC. In: WAMBIER, Teresa Arruda Alvim; NERY JÚNIOR, Nelson (Orgs.). Aspectos polêmicos e atuais dos recursos cíveis e de outros meios de impugnação às decisões judiciais. v. 7. São Paulo: Revista dos Tribunais, 2003, p. 5.

${ }^{26}$ CIANCI, Mirna. A Lei 9.756/1988 (arts. 544, $\$ 3^{\circ}$ e 557, $\S \S 1^{\circ}$ A e $3^{\circ}$ do CPC) e a ampliação dos poderes do relator - dez anos depois. Revista dos Tribunais, São Paulo, n. 157, Março/2008, p. 167.

27 "Pode o relator negar seguimento ao recurso, considerando-o manifestamente improcedente, hipótese em que se está diante de exercício de juízo de mérito negativo, apesar de o legislador usar a expressão negar seguimento" (WAMBIER, Teresa Arruda Alvim. Os agravos no CPC brasileiro. 4. ed. São Paulo: Revista dos Tribunais, 2004, p. 548).

${ }^{28}$ SLAIBI FILHO, Nagib. Notas sobre o art. 557 do CPC. Competência do relator de prover e de negar seguimento a recurso. Jus Navigandi, Teresina, ano 8, n. 62,1 fev. $2003 . \quad$ Disponível em: <http://jus.com.br/artigos/3792>. Acesso em 13 de outubro de 2013.
} 


\section{Volume VIII | Número 2 | Ano 2013}

cognição que seria feita pelo órgão competente (como diz a lei) forçando o decisor monocrata a projetar o seu espírito no adiantamento daquilo que razoavelmente seria decidido por seus pares".

Para Sérgio Cruz Arenhart ${ }^{29}$, manifestamente improcedente significa hipótese de improcedência da tese jurídica sustentada em sede recursal "em que esta evidência será revelada exatamente pela existência do contraste do recurso com súmula ou jurisprudência dominante do próprio tribunal ou dos Tribunais Superiores".

Perquire-se sobre a postura mais adequada do relator frente aos requisitos de manifesta improcedência e de manifesto confronto com jurisprudência dominante. Considerar, isoladamente, a manifesta improcedência como uma justificativa para a aplicação dos poderes monocráticos do relator encerra uma situação de excessiva subjetividade. Poderá o relator, o qual atua como delegado do colegiado aplicar o posicionamento do ente delegante, mesmo se este não se enquadrar no segundo requisito? Ou melhor: o prestígio da opinião que prevalece no órgão fracionário, ou mesmo no próprio tribunal em si poderá prevalecer em detrimento do posicionamento majoritário (jurisprudência dominante) adotado pelos tribunais de cúpula? É cabível que o magistrado singular utilize de sua discricionariedade ao escolher o paradigma?

Mediante breve leitura da norma e destaque de alguns posicionamentos supra, poderia entender-se que sim. Porém, tal concepção não se harmoniza com a finalidade preconizada pelo legislador ordinário, que é justamente fixar requisitos taxativos concedentes de atuação solitária de modo a atribuir coerência ao sistema processual como um todo. A interpretação literal também não se coaduna com a intenção constitucional de estabelecer o julgamento colegiado como a regra, de sorte a tornar excepcionalíssimas as hipóteses legais de julgamento recursal monocrático.

Para resolver este primeiro impasse, sustenta-se que o requisito da manifesta improcedência não deverá ser interpretado como uma hipótese permissiva autônoma. Assim, para que seja um recurso julgado monocraticamente por sua manifesta improcedência, necessário se faz averiguar se a tese jurídica sustentada também se encontra em manifesta dissonância com o posicionamento dominante dos Tribunais Superiores. ${ }^{30}$ Partindo-se do

\footnotetext{
${ }^{29}$ ARENHART, Sérgio Cruz. A nova postura do relator no julgamento dos recursos. Revista de Processo, São Paulo, a. 26, n. 103, Julho/Setembro 2001, p. 37.

30“"Melhor teria posto o legislador se tivesse reunido essas duas situações, de molde a exigir, expressamente, que a consideração como "manifestamente improcedente" tivesse o significado de confronto entre as razões recursais e a reiterada postura do colegiado ou das Cortes Superiores. Do modo como consta, revelou-se fluido o conceito, parecendo que seria a juízo único do relator a análise do mérito recursal, exceto se fosse possível admitir que a lei poderia conter expressão inútil, a ponto de trazer em seu contexto dois pressupostos idênticos e, ao mesmo
} 
pressuposto de que a manifesta improcedência recursal depende da configuração do confronto com a jurisprudência dominante do respectivo tribunal, STF e dos Tribunais Superiores ${ }^{31}$, passa-se à busca do real conteúdo deste conceito jurídico tão indeterminado.

\subsubsection{Recurso em confronto com súmula ou jurisprudência dominante}

Tendo em vista que o objeto da presente pesquisa é fixar parâmetros mais claros para a aplicação do art. 557, caput, do CPC, acredita-se ser desnecessário o enquadramento da hipótese do recurso destoar de súmula do respectivo tribunal, do STF ou de Tribunal Superior num tópico próprio, pelo fato de a lei e os regimentos internos dos tribunais já definirem as hipóteses em que determinada questão deva ser súmula. Assim, conforme preceitua o art. 479, caput, do CPC “o julgamento, tomado pelo voto da maioria absoluta dos membros que integram o Tribunal, será objeto de súmula e constituirá precedente na uniformização da jurisprudência". Já o art. 122, §1º, parte final, do RISTJ preceitua, exemplificativamente: “Também poderão ser inscritos na súmula os enunciados correspondentes às decisões firmadas por unanimidade dos membros componentes da Corte Especial ou da Seção, em um caso, ou por maioria absoluta em pelo menos dois julgamentos concordantes."

Prosseguindo, cumpre indagar sobre o real significado, bem como o meio de se avaliar sua presença casuisticamente. Pelo posicionamento adotado por Sérgio Cruz Arenhart e Luiz Guilherme Marinoni ${ }^{32}$ seria extremamente superficial assimilar que a jurisprudência dominante de certo tribunal fosse "aquela que predomina naquela específica instância. Porém, essa resposta esconde inúmeras perguntas que poderia formular e deixa em aberto toda a caracterização do que seria jurisprudência dominante ".

É cediço que jurisprudência dominante não equivale à jurisprudência pacífica, haja vista que a última se refere à inexistência de relevante oposição, e dominante indica a

tempo, alternativos" (CIANCI, Mirna. A Lei 9.756/1988 (arts. 544, $\S 3^{\circ}$ e $557, \S \S 1^{\circ}$ A e $3^{\circ}$ do CPC) e a ampliação dos poderes do relator - dez anos depois. Revista dos Tribunais, São Paulo, n. 157, Março/2008, p. 167).

31“'O ‘tribunal superior’ de que fala a lei só pode ser o próprio STJ, já que, em função de regras delimitadoras da competência, o TST, o STM e o TSE dificilmente terão súmula ou jurisprudência que possa influir em julgado da justiça cível" (WAMBIER, Teresa Arruda Alvim. Os agravos no CPC brasileiro. 4. ed. São Paulo: Revista dos Tribunais, 2004, p. 549).

32 ARENHART, Sergio Cruz; MARINONI, Luiz Guilherme. Curso de Processo Civil. v. 2. São Paulo: Revista dos Tribunais, 2013, pp. 588-589. 
jurisprudência que predomina na orientação do órgão colegiado, ainda que pese contra ela outra ideia ou concepção. ${ }^{33}$

No estudo mais profundo do real conteúdo inerente ao vocábulo, Priscila Kei Sato ${ }^{34}$ debruça-se sobre a definição de jurisprudência dominante, com o fito de auferir sua verdadeira ótica, estabelecendo como válidos dois meios de verificação: a) a existência de um número plural de acórdãos que manifeste o posicionamento em questão ou, alternativamente: b) a ocorrência de decisão do pleno em um determinado sentido, mesmo que de forma não unânime. No que concerne aos Tribunais de Justiça dos Estados, em função de seu maior fracionamento, visualiza-se ser necessária a adoção de outros padrões.

Já Sérgio Cruz Arenhart ${ }^{35}$ sustenta que, pelo fato da súmula refletir justamente o entendimento consolidado pela Corte, razoável é a compreensão de o vocábulo jurisprudência dominante, circunstância que permite a aplicação do art. 557 do CPC possa ser assimilado como uma "decisão objeto de incidente de uniformização de jurisprudência onde não se logrou atingir o quórum especial, exigido para a elaboração de uma súmula”.

Conquanto tais constatações apresentem critérios razoáveis à conceituação de jurisprudência dominante, estes ainda não se mostram suficientes: no primeiro caso critérios adotados por Kei Sato - porque os requisitos quantitativo e qualitativo são alternativos, o que nem sempre se afigura satisfatório, e, no segundo, porquanto somente alude à existência de um quórum mínimo, desprezando outras situações em que a jurisprudência possa ser considerada dominante. Deve-se ter em mente que a norma insculpida no art. 557 do CPC faz referência ao entendimento do STJ ou STF por ser destes as funções nomofilácica e uniformizadora sobre a matéria federal e constitucional; por tal motivo é que só deverão os tribunais locais firmar interpretação própria quando esta se fizer estritamente alinhada ao entendimento daquelas Cortes ou se a jurisprudência for dominante no âmbito do tribunal local e não houver enfrentamento da questão no tribunal de superposição, ocorrendo uma situação de ausência de conflito de entendimentos. Em síntese, a jurisprudência do tribunal local só será considerada dominante se em conformidade com a do STJ ou do STF, ou, pelo menos, se com ela não conflitar.

\footnotetext{
${ }^{33}$ ARENHART, Sergio Cruz; MARINONI, Luiz Guilherme. Curso de Processo Civil. v. 2. São Paulo: Revista dos Tribunais, 2013, pp. 588-589.

${ }^{34}$ SATO, Priscilla Kei. Jurisprudência (pre)dominante. In: WAMBIER, Teresa Arruda Alvim; NERY JÚNIOR, Nelson (Orgs.). Aspectos polêmicos e atuais dos recursos. São Paulo: Revista dos Tribunais, 2000, p. 583.

${ }^{35}$ ARENHART, Sergio Cruz; MARINONI, Luiz Guilherme. Curso de Processo Civil. v. 2. São Paulo: Revista dos Tribunais, 2013, p. 586.
} 
Ainda, é importante que a jurisprudência do tribunal local não esteja em contraste com o entendimento de outros tribunais locais. Nestes casos, embora a lei dê a entender que seja suficiente a predominância no tribunal local, o fato de haver entendimento em contrário em outros tribunais locais sinaliza a possibilidade de reforma nos tribunais Superiores ${ }^{36}$. E, para este fim, o interessado será obrigado a interpor agravo interno, obter uma decisão colegiada para, depois, interpor o recurso excepcional. Só por esta razão, o julgamento monocrático já perde a utilidade do ponto de vista prático, porque pode gerar irresignação justificada ${ }^{37}$.

É preciso verificar, outrossim, se o entendimento é predominante ao tempo em que se julga ou se houve algum julgado que esboçasse razões suficientes para considerá-lo superado (como no overruling da common law). ${ }^{38}$ Ainda, pode ocorrer de o caso apresentar especificidades que tornem a jurisprudência dominante inaplicável ou de difícil aplicação àquele caso (possível distinguishing), ${ }^{39}$ hipóteses em que não será possível o julgamento monocrático.

Outro parâmetro de aplicação razoável é aquele destacado por Luiz Rodrigues Wambier ${ }^{40}$, no sentido de ser reputado dominante, por exemplo, um posicionamento do STF ou do STJ demonstrado por meio de reiteradas decisões em uma ordem mínima de 70\%,

36 "Se o que marca o sistema do art. 557, caput, e $\$ 1^{\circ}$., é ser manifesto, parece que, havendo jurisprudência dominante, mas diferente dos diversos Tribunais, ou mesmo súmulas antagônicas o relator não deverá agir individualmente, devendo, então, sempre, remeter o processo a julgamento colegiado. Se as orientações de jurisprudência forem congruentes ou se as súmulas forem do mesmo sentido, constata-se a presença de um referencial seguro para decidir" (WAMBIER, Teresa Arruda Alvim. Os agravos no CPC brasileiro. 4. ed. São Paulo: Revista dos Tribunais, 2004, p. 560).

${ }^{37}$ De acordo com o posicionamento adotado pelo STJ, “a expressão 'jurisprudência dominante do respectivo tribunal' somente pode servir de base para negar seguimento a recurso quando o entendimento adotado estiver de acordo com a jurisprudência do STJ e do STF, sob pena de negar às partes o direito constitucional de acesso às vias extraordinárias" (STJ, REsp 193.189/CE, Relator Ministro FRANCIULLI NETTO, SEGUNDA TURMA, DJU: 21 de agosto de 2000).

${ }^{38} \mathrm{O}$ overruling se refere ao mecanismo hábil ao reconhecimento de fundamentação suficiente ao abandono de determinado precedente utilizado em razão da modificação de interpretação da ratio decidendi da decisão que formou o precedente. Sendo assim, o próprio Tribunal que firmou determinado posicionamento poderá abandoná-lo futuramente, declarando-o superado (Novas súmulas do STF e alguns reflexos sobre o mandado de segurança. Mundo Jurídico. Disponível em: <http://www.mundojuridico.adv.br/sis_artigos/artigos.asp?codigo=238>. Acesso em 27 de maio de 2013).

${ }^{39} \mathrm{O}$ conceito de distinguishing se refere ao cotejo analítico realizado pelo magistrado, por meio do qual verifica se o caso em julgamento pode ou não ser considerado ao paradigma. (CRUZ e TUCCI, José Rogério. Precedente Judicial como Fonte do Direito. São Paulo: Revista dos Tribunais, 2004, p. 170).

Em pesquisa aprofundada sobre o tema, Daniela Pereira Madeira entabula duas ocasiões passíveis de utilização do distinguishing: a) para designar o método de comparação entre o caso concreto e o paradigma (distinguishmétodo); e b) para designar o resultado desse confronto, nos casos em que se conclui haver entre eles alguma diferença (distinguish-resultado) (MADEIRA, Daniela Pereira. A força da jurisprudência. O Novo Processo Civil Brasileiro, Direito em Expectativa: Reflexões acerca do Projeto do Novo Código de Processo Civil. Coordenação: Luiz Fux. Rio de Janeiro: Forense, 2011, p. 539).

40 WAMBIER, Luiz Rodrigues. Uma proposta em torno do conceito de jurisprudência dominante. Revista Jurídica Mater Dei, Pato Branco-PR, v. 1, n. 1, jul./dez., pp. 9-18. Disponível em: < http://www.materdei.edu.br/Arquivos/Revistas/7/19_08_201310_41_41REVISTAJURDICAMATERDEIvolum e1.pdf >. Acesso em 10 de agosto de 2013. 


\section{Volume VIII | Número 2 | Ano 2013}

dentro de um período de cinco anos (ou de outro determinado período fixado), computados retroativamente.

Para o alcance do objetivo quanto à fixação de balizas à aferição do real conteúdo do vocábulo jurisprudência dominante, um dos requisitos que autorizam a decisão monocrática do art. 557 do CPC, esta pesquisa organiza os critérios acima demonstrados em duas modalidades: parâmetros qualitativos e quantitativos.

Qualitativamente, a jurisprudência será dominante após a observação de três diretrizes: a) reputar dominante tão somente a jurisprudência do STJ e do STF, sendo também possível considerar dominante a jurisprudência do tribunal em que tramita o recurso no caso desta guardar sintonia com posicionamento manifestado pelos órgãos de cúpula ou se destes não se destoar e, desde que outro tribunal não firme posicionamento em outro sentido; b) deve ser respeitado o quórum qualificado ou de maioria simples do pleno ou órgão especial, na oportunidade em que não se logrou êxito em atingir o número suficiente à elaboração de súmula e; c) a ausência de overruling ou distinguishing deve ser compreendida como requisito negativo.

Ademais, também é possível a submissão da análise do conceito a um critério quantitativo, que considera a proporção das decisões exaradas em torno de uma dada disciplina e o tempo em que determinada orientação permanece passível de ser conservada como formadora de uma jurisprudência dominante ${ }^{41}$. Este critério, porém, deve ser cumulado com os parâmetros qualitativos descritos nas letras a e c, supra.

Tal questão adquire ainda mais relevo, pois dentre os critérios de aplicação já mencionados, o relator somente poderá julgar o recurso se acerca de casos semelhantes já houver posicionamento sedimentado e respeitado pelas Cortes Superiores acerca da matéria, havendo um comprometimento da liberdade decisória do magistrado, por relativizar sua independência em função do prestígio à uniformização e celeridade.

Observa-se que a norma passa a ser assimilada não mais pela lei que a estabelece, mas sim pela interpretação que os tribunais Superiores realizam; o que significa dizer que o jurisdicionado contemporâneo passa a se valer não somente da hermenêutica pessoal que exerce, mas do posicionamento jurisprudencial. Fala-se então, na igualdade perante a

\footnotetext{
${ }^{41}$ Ademais, quando ao conceito de jurisprudência dominante, não parece exagero sustentar-se que a jurisprudência dominante é aquela que já poderia estar sumulada. É aquela que diz respeito a um tal número de acórdãos, que permite a inferência no sentido de que a opinião do tribunal àquele respeito não deve alterar-se (WAMBIER. Teresa Arruda Alvim. Os agravos no CPC brasileiro. 4 ed. São Paulo: Revista dos Tribunais, 2004).
} 


\section{Volume VIII | Número 2 | Ano 2013}

jurisprudência, não apenas à lei. Frise-se com convicção que o vocábulo jurisprudência dominante, constado do art. 557 do CPC reflete um dos sintomas mais notórios de que o ordenamento jurídico pátrio começa a caminhar para a uniformização da jurisprudência, entretanto, para alcançar seu mais alto grau de eficácia e de unidade sistêmica, imprescindível é que saibamos avaliar as circunstâncias determinadamente e não quedarmos inertes, aplicando o conceito de modo tão inconsequente e irresponsável, como atualmente ${ }^{42}$.

Aliada a esses fatores, a aplicação desse instituto necessita do redimensionamento da regra da motivação. Logo, toda vez que o magistrado solitário for julgar o caso, terá que se valer de uma motivação que permita abraçar casos semelhantes àquele, de modo a não gerar dúvidas futuras quanto à interpretação dos precedentes, investigando se aquele determinado caso reúne as circunstâncias necessárias à incidência daquela jurisprudência dominante.

\footnotetext{
${ }^{42}$ Colaciona-se um julgado que veicula hipótese em que o recurso não deveria sequer ter sido admitido, porque a sua regularidade esbarrava em súmula (ou seja, o relator julgou contra a súmula):

EMENTA: "AGRAVO REGIMENTAL. RECURSO ESPECIAL. PROCESSO CIVIL. VIOLAÇÃO DO ART. 535 DO CPC. INVOCAÇÃO DE DISPOSITIVOS QUE NÃO SUSTENTAM A TESE DEFENDIDA. NÃO OCORRÊNCIA. SÚMULA N. 284/STF.1. Afasta-se a alegada violação do art. 535 do CPC quando o acórdão recorrido, integrado pelo julgado proferido nos embargos de declaração, dirime, de forma expressa, congruente e motivada, as questões suscitadas nas razões recursais.2. Incide o óbice previsto na Súmula n. 284 do STF na hipótese em que a deficiência da fundamentação do recurso não permite a exata compreensão da controvérsia.3. Agravo regimental provido em parte para não conhecer do recurso especial por novos fundamentos." (STJ AgRg no REsp 1214795/PE - Rel. Ministro JOÃO OTÁVIO DE NORONHA - TERCEIRA TURMA - julgado em 25/06/2013, DJE 28/06/2013).

Disponível em:<http://www.stj.gov.br/SCON/jurisprudencia/toc.jsp〉, acessado em 19 agosto de 2013.

Noutro julgado, em sede de agravo interno do art. $557 \S 1^{\circ}$ do CPC, a relatora constatou que jamais poderia ter sido a apelação decidida monocraticamente por envolver matéria fática na questão recorrida, não fazendo-se presentes as hipóteses que ensejam a decisão singular prevista no dispositivo sob análise. Veja-se: VOTO: “(...) No caso em questão, verifica-se que a decisão recorrida trata, em grande parte, de matéria fática e, portanto, diversa da prevista nos estritos limites do art. 557 do Código de Processo Civil. Desse modo, a matéria enfocada nos presentes autos deve ser submetida ao órgão colegiado competente, eis que para a análise das questões que compõe o objeto do pedido, não se fazem presentes as hipóteses do art. 557 e $\$ 1^{\circ}$-A do Código de Processo Civil (...) $\mathrm{O}$ artigo 557 §1-A refere-se à decisão recorrida que esteja em manifesto confronto com súmula ou jurisprudência dominante no Supremo Tribunal Federal ou Tribunal Superior. A meu ver, a r. sentença de fls. 258/260 não contém essas características. Ao contrário, analisa a extensa matéria de fato encontrada na documentação acostada aos autos e aplica os dispositivos legais nos quais subsumida a questão (...) Por conseguinte, dou provimento ao agravo legal para declarar a nulidade da decisão monocrática, impondo-se o prosseguimento do recurso, afim de ser julgado pelo Órgão Colegiado, razão pela qual conheço da apelação, passando à sua análise." (TRF3 - AgRg 20060399.011042-4 na AC 1099301/ SP - Rel. Desembargadora Federal LEIDE POLO - SÉTIMA TURMA - DJE DA $3^{a}$ REGIÃO - DECISÃO DE FLS. 280/303 - Data de Divulgação: $18 / 02 / 2009)$.
} 


\title{
Volume VIII | Número 2 | Ano 2013
}

\section{TENDÊNCIAS E EXPECTATIVAS DO NOVO CÓDIGO E A FORÇA DA JURISPRUDÊNCIA}

Sabe-se que o Senado Federal instaurou (ato $n^{\circ} .379$ de 30 de setembro de 2009) uma Comissão de pensadores do Direito, à busca da confecção de um Anteprojeto do Novo Código de Processo Civil.

Dessa forma, o PLS de nº 166, após haver sofrido alterações, seguiu à Câmara dos Deputados (PL 8.046/2010), sendo aprovado em 17.07.2013 com a conclusão dos destaques pela Comissão Especial incumbida de apreciar o projeto.

Inspirada nos ensinamentos de Mauro Cappelletti e Bryan Garth ${ }^{43}$, a Comissão encabeçada por seu Presidente, o Ministro Luiz Fux e Tereza Arruda Alvim Wambier (Relatora), dedicou-se aprofundar a investigação acerca dos fatores que dificultam o amplo acesso à justiça, obtendo, por fim, a compreensão de que os aspectos inerentes à estrutura ao aparato processual apresentavam "solenidades obrigatórias que por si só contribuíam para a demora da resposta judicial ${ }^{44}$ ". E prossegue o Ministro Luiz Fux ${ }^{45}$ :

\begin{abstract}
Ressoa evidente que as três causas importantes reclamam ser enfrentadas: as excessivas solenidades processuais, das quais o processo civil brasileiro encontravase prenhe; o excesso número de demandas e a prodigalidade recursal na ótica antes apontada. O desafio releva-se tanto maior na medida em que impunha supressões no sistema processual mercê de garantias constitucionais dirigidas ao legislador ordinário; como v.g, o contraditório, o devido processo legal, a ampla defesa e os recursos a ela inerentes, dentre outros.
\end{abstract}

Afirma-se com clareza que dentre as modificações mais notáveis do pensamento crítico expressado pelo Código Projetado, duas tendências pontuais impactaram diretamente: a) a constatação de que o princípio é norma jurídica e muitos foram positivados pela nova legislação processual; e b) a circunstância de que a jurisprudência predominante consiste em norma jurídica distinta da lei, sendo que faz parte da função jurisdicional a aplicação dessa norma jurisprudencial.

Incumbido, outrossim, da tarefa de avaliar a postura do Projeto do Novo Código de Processo Civil em relação às hipóteses que autorizam a decisão monocrática veiculadas pelo art. 557 do atual CPC, constata-se que os argumentos até aqui utilizados são corroborados

\footnotetext{
43 CAPPELlETTI, Mauro; GARTH, Bryant. Acesso à Justiça. Tradução de Ellen Gracie Northfleet. Porto Alegre: Fabris 1988, Reimpresso em 2002.

${ }^{44}$ FUX, Luiz. O Novo Processo Civil Brasileiro, Direito em Expectativa: Reflexões acerca do Projeto do Novo Código de Processo Civil. Rio de Janeiro: Forense, 2011, p. 2.

${ }^{45}$ Idem, ibidem, loc. cit.
} 


\section{Volume VIII | Número 2 | Ano 2013}

com as novas tendências trazidas, nos moldes do projetado art. 945 (presente redação do dispositivo dada após a aprovação pelo órgão especial da Câmara dos Deputados):

Art. 945. Incumbe ao relator:

(...)

III: não conhecer de recurso inadmissível, prejudicado ou que não tenha impugnado especificamente os fundamentos da decisão recorrida;

IV: negar provimento a recurso que for contrário a:

a) súmula do Supremo Tribunal Federal, do Superior Tribunal de Justiça ou do próprio tribunal;

b) acórdão proferido pelo Supremo Tribunal Federal ou pelo Superior Tribunal de Justiça em julgamento de recursos repetitivos;

c) entendimento firmado em incidente de resolução de demandas repetitivas ou de assunção de competência.

$\mathrm{V}$ : depois de facultada, quando for o caso, a apresentação de contrarrazões, dar provimento ao recurso se a decisão recorrida for contrária a:

a) súmula do Supremo Tribunal Federal, do Superior Tribunal de Justiça ou do próprio tribunal;

b) acórdão proferido pelo Supremo Tribunal Federal ou pelo Superior Tribunal de Justiça em julgamento de recursos repetitivos;

c) entendimento firmado em incidente de resolução de demandas repetitivas ou de assunção de competência.

(...)

Parágrafo único. Antes de considerar inadmissível o recurso, o relator concederá o prazo de cinco dias ao recorrente para que seja sanado vício ou complementada a documentação exigível.

Percebe-se que o Projeto do Novo CPC não mantém em sua redação que equivale ao dispositivo em análise, as terminologias jurisprudência dominante e manifesta improcedência, além de riscar a expressão manifestamente - no que já não indicava alguma vantagem em permanecer na legislação.

Além disso, o termo não conhecer passa a se referir, tão somente, às hipóteses de recurso inadmissível ou prejudicado, caminhando no rumo certo em deixar a expressão de maior técnica - negar provimento - quando o relator adentrar na análise meritória. Nota-se que esta hipótese exige o mesmo raciocínio desenvolvido ao longo do texto, uma vez que, mesmo sendo substituído jurisprudência dominante por "a decisão proferida pelo Supremo Tribunal Federal ou por Tribunal Superior em casos repetitivos", esta última passa a exigir a aplicação dos critérios quantitativos e qualitativos destacados.

\section{CONSIDERAÇÕES FINAIS}

A busca pela exegese restritiva das circunstâncias que autorizam a decisão monocrática, sobretudo no que se refere ao art. 557, caput, do CPC realizou-se à luz do princípio da colegialidade, compreendido como verdadeira garantia constitucional implícita, 
decorrente dos postulados da separação e independência dos Poderes e do direito à prestação jurisdicional justa e efetiva. Foi demonstrado, ainda, que a colegialidade corresponde justamente ao combustível que propicia a reflexão, interferindo de tal modo que as decisões exaradas pelos órgãos plurais estão mais tendentes ao acerto.

Face ao viés inexoravelmente axiológico que comporta, o princípio da colegialidade será passível de ponderação com outras garantias constitucionais, como, v.g, o princípio da celeridade e economia processual, mas, para tanto, figura-se medida necessária adotar as seguintes premissas, hábeis a propiciar o julgamento monocrático em sede recursal previsto pelo art. 557 do CPC: a) o requisito manifestamente improcedente não constitui pressuposto autônomo veiculador de fundamentação que autorize a atuação singular do relator; b) o magistrado solitário permanece adstrito ao posicionamento predominante das Cortes Superiores, em caso de confronto entre a pretensão recursal e a jurisprudência, o que significa dizer que a boa exegese da norma não o autoriza em prestigiar o direcionamento prevalente no tribunal local em detrimento do entendimento consolidado pelo STJ, STF, tratando-se de matéria federal e constitucional respectivamente; c) a terminologia jurisprudência dominante se refere apenas ao posicionamento majoritário dos tribunais de superposição ou dos tribunais locais desde que não confrontantes com o posicionamento majoritário de outros Tribunais de Justiça, STF e STJ em determinado lapso temporal, devendo ser respeitado o quorum qualificado ou de maioria simples do pleno ou órgão especial, na oportunidade em que não se logrou êxito em atingir o número suficiente à elaboração de súmula, d) sendo que a ausência de overruling ou distinguishing deverá ser compreendida como requisito negativo à aplicação da orientação dominante - aspectos qualitativos e quantitativos, constatação que precisa se pautar em acessos a sistemas de dado eficientes, disponibilizados pelos tribunais. Ainda, também é possível a submissão da análise do conceito a um critério quantitativo, que considera a proporção das decisões exaradas em torno de uma dada disciplina e o tempo em que determinada orientação permanece passível de ser conservada como formadora de uma jurisprudência dominante. Este critério, porém, deve ser cumulado com os parâmetros qualitativos descritos nas letras a, b e d, retro.

Chegou-se à conclusão de que a atuação monocrática desenfreada, sem a observância de parâmetros bem traçados, jamais poderá ser admitida e quiçá justificada sob a perspectiva da celeridade e economia processual, sob pena de se desrespeitarem os princípios constitucionais basilares do Estado Democrático de Direito, bem como de contribuir para a 


\section{Volume VIII | Número 2 | Ano 2013}

fossilização da jurisprudência, pois como já dizia o mestre Barbosa Moreira ${ }^{46}$ : "a lei do menor esforço não é necessariamente, sob quaisquer condições, boa conselheira".

Finalmente, porém não menos importante, não se pode fechar os olhos para a nova codificação que se aproxima. Percebeu-se que este movimento de reorganização dos institutos processuais decorre do raciocínio empreendido pelos juristas destes novos tempos, os quais passam a desenhar a estrutura normativa conforme a forma de se pensar o Direito hodiernamente. Uma das grandes inovações se refere à força normativa da jurisprudência, que no decorrer do trabalho foi analisada como uma das justificativas de se autorizar que o relator julgue monocraticamente o recurso, sendo potencializada de tal forma que os parâmetros ora mencionados são fundamentais para que se comece a compreender a metodologia trazida pelo Código Projetado, a qual passa a exigir o mínimo de sofisticação do operador ao aplicá-la.

Considerando os argumentos e constatações expostas, fica o seguinte convite à reflexão: será que a comunidade jurídica está realmente preparada para tamanha mudança de paradigma?

\section{REFERÊNCIAS}

ARENHART, Sérgio Cruz. A nova postura do relator no julgamento dos recursos. Revista de Processo, São Paulo, a. 26, n. 103, Julho/Setembro 2001, pp. 37-58.

.; MARINONI, Luiz Guilherme. Curso de Processo Civil. vol. 2. São Paulo: Revista dos Tribunais, 2013.

ÁVILA, Humberto. O que é “devido processo legal”. In: DIDIER JR., Fredie (Org.). Leituras complementares de Processo Civil. 5. ed. Salvador: Jus Podivm, 2010.

BEDAQUE, José Roberto dos Santos. Efetividade do processo e técnica processual. 3. ed. São Paulo: Malheiros, 2010.

\footnotetext{
${ }^{46}$ MOREIRA, José Carlos Barbosa. Comentários ao Código de Processo Civil. v. V. 11. ed. Rio de Janeiro: Forense, 2003, p. 663.
} 


\section{Volume VIII | Número 2 | Ano 2013}

BRANCO, Paulo Gustavo Gonet; COELHO, Inocêncio Mártires; MENDES, Gilmar Ferreira. Curso de Direito Constitucional. 4. ed. São Paulo: Saraiva, 2009.

CAMBI, Acácio. Aspectos polêmicos na aplicação do art. 557 do CPC. In: WAMBIER, Teresa Arruda Alvim; NERY JÚNIOR, Nelson (Orgs.). Aspectos polêmicos e atuais dos recursos cíveis e de outros meios de impugnação às decisões judiciais. v. 7. São Paulo: Revista dos Tribunais, 2003.

CANOTILHO, J.J. Gomes. Direito Constitucional e Teoria da Constituição. Coimbra: Almedina, 2007.

CAPPELLETTI, Mauro; GARTH, Bryant. Acesso à Justiça. Tradução de Ellen Gracie Northfleet. Porto Alegre: Fabris 1988, Reimpresso em 2002.

CARNEIRO, Athos Gusmão. Poderes do relator e Agravo Interno - Art. 557, 544 e 545 do CPC. Doutrinas essenciais de Processo Civil. v. 7. São Paulo: Revista dos Tribunais, 2011.

CARVAlHO FILHO, José dos Santos. Manual de Direto Administrativo. 23. ed. Rio de Janeiro: Lumen Juris, 2010.

CIANCI, Mirna. A Lei 9.756/1988 (arts. 544, $\S 3^{\circ}$ e 557, $\S \S 1^{\circ}$ A e $3^{\circ}$ do CPC) e a ampliação dos poderes do relator - dez anos depois. Revista dos Tribunais, São Paulo, v. 33, n. 157, Março/2008, pp. 165-181.

CINTRA, Antônio Carlos Araújo; DINAMARCO Cândido Rangel; GRINOVER Ada Pellegrini. Teoria Geral do Processo. 26. ed. São Paulo: Malheiros, 2010.

COHENDET, Marie-Anne. La Collégialité des Juridictions: un principe en voie de disparition. Revue Française de Droit Constitutionnel, Paris, n. 68, 2006, pp. 713-735.

CRUZ e TUCCI, José Rogério. Precedente Judicial como Fonte do Direito. São Paulo: Revista dos Tribunais, 2004.

DINAMARCO, Cândido Rangel. O relator, a jurisprudência e os recursos. In: WAMBIER, Teresa Arruda Alvim; NERY JÚNIOR, Nelson (Orgs.). Aspectos polêmicos e atuais dos recursos cíveis de acordo com a Lei 9.756/98. São Paulo: Revista dos Tribunais, 1998.

FRANÇOLIN, Wanessa de Cássia. A ampliação dos poderes do relator nos recursos cíveis. Rio de Janeiro: Forense, 2006. 
FUX, Luiz. Carta de encaminhamento do Anteprojeto do Novo Código de Processo Civil ao Senado Federal. Anteprojeto do Código de Processo Civil. Brasil. Congresso Nacional. Senado Federal: Presidência da República. Brasília, 2010. Disponível em: $<$ http://www.senado.gov.br/senado/novocpc/pdf/anteprojeto.pdf $>$. Acesso em 08 de maio de 2013.

O Novo Processo Civil Brasileiro, Direito em Expectativa: Reflexões acerca do Projeto do Novo Código de Processo Civil. Rio de Janeiro: Forense, 2011.

GRECO, Leonardo. A Falência dos sistemas de recursos. Revista dialética de direito processual, São Paulo, v. 1, Abril/2003, pp. 93-108.

Jurídico.
Novas súmulas do STF e alguns reflexos sobre o mandado de segurança. Mundo
em: <http://www.mundojuridico.adv.br/sis_artigos/artigos.asp?codigo=238>. Acesso em 27 de maio de 2013.

Princípios de uma teoria geral dos recursos. Revista Eletrônica de Direito Processual, Rio de Janeiro, ano 4, v. V, 2010, pp 5-62. Disponível em: <http://www.redp.com.br/edicao_05.htm>. Acesso em 17 de julho de 2013.

MADEIRA, Daniela Pereira. A força da jurisprudência. In: FUX, Luiz (Org.). O Novo Processo Civil Brasileiro, Direito em Expectativa: Reflexões acerca do Projeto do Novo Código de Processo Civil. Rio de Janeiro: Forense, 2011.

MENDONÇA, Henrique Guelber de. O Princípio da colegialidade e o papel do relator no processo civil brasileiro. Revista Eletrônica de Direito Processual, Rio de Janeiro, 1. ed., Outubro a Dezembro de 2007, pp. 208-225. Disponível em: <http://www.redp.com.br/arquivos/redp_1a_edicao_rj.pdf>, acessado em 10 de junho de 2013.

MITIDIERO, Daniel. Direito Fundamental ao Processo Justo. Disponível em: 〈http://www.rkladvocacia.com/arquivos/artigos/art_srt_arquivo20130419164953.pdf >. Acesso em 28 de novembro de 2013.

MOREIRA, José Carlos Barbosa. Comentários ao Código de Processo Civil. v. V. 11. ed. Rio de Janeiro: Forense, 2003. 
NERY JÚNIOR, Nelson. Teoria geral dos Recursos. 6. ed. São Paulo: Revista dos Tribunais, 2004.

OLIVEIRA, Carlos Alberto Alvaro de. Os Direitos Fundamentais à Efetividade e à Segurança em Perspectiva Dinâmica. Disponível em: <http://www.oab.org.br/editora/revista/users/revista/1222961767174218181901.pdf>. Acesso em 28 de novembro de 2013.

SATO, Priscilla Kei. Jurisprudência (pre)dominante. In: WAMBIER, Teresa Arruda Alvim; NERY JÚNIOR, Nelson (Orgs.). Aspectos polêmicos e atuais dos recursos. São Paulo: Revista dos Tribunais, 2000.

SLAIBI FILHO, Nagib. Notas sobre o art. 557 do CPC. Competência do relator de prover e de negar seguimento a recurso. Jus Navigandi, Teresina, ano 8, n. 62, 1 fev. 2003. Disponível em: <http://jus.com.br/artigos/3792>. Acesso em 13 de outubro de 2013.

TARUFFO, Michele. Idee per una Teoria della Decisione Giusta, Sui Confini - Scritti sulla Giustizia Civile. Bologna: Il Mulino, 2002.

TAVARES, Diogo Ferraz Lemos. Princípio da Colegialidade: fundamento constitucional e necessidade de sua observância nos processos judiciais e administrativos legitimidade/ilegitimidade de exceções. Revista Eletrônica de Direito Processual, Rio de Janeiro, a. 5, v. VIII, Julho/2011, pp. 233-259. Disponível em: < http://www.redp.com.br/arquivos/redp_8a_edicao.pdf>. Acesso em 08 de julho de 2013.

WAMBIER, Luiz Rodrigues. Uma proposta em torno do conceito de jurisprudência dominante. Revista Jurídica Mater Dei, Pato Branco-PR, v. 1, n. 1, jul./dez., pp. 9-18. Disponível em:

http://www.materdei.edu.br/Arquivos/Revistas/7/19_08_201310_41_41REVISTAJURDICA MATERDEIvolume1.pdf > . Acesso em 10 de agosto de 2013.

WAMBIER, Teresa Arruda Alvim. Os agravos no CPC brasileiro. 4. ed. São Paulo: Revista dos Tribunais, 2004. 